\title{
Sistem Pendukung Keputusan Pemilihan Tumbuhan Berkhasiat Obat Menggunakan Metode Analytical Hierarchy Process- Weighted Product
}

\author{
Masna Wati ${ }^{\text {a, }{ }^{*} \text {, Andi Maulana }}{ }^{\mathrm{a}, 2}$ dan Joan Angelina Widians ${ }^{\mathrm{a}, 3}$ \\ ${ }^{a}$ Universitas Mulawarman, Kampus Gunung Kelua Kota Samarinda, Kalimantan Timur 75117, Indonesia \\ ${ }^{1}$ masnawati@fkti.unmul.ac.id; ${ }^{2}$ andimaulana1213@gmail.com; ${ }^{3}$ angel.unmul@gmail.com \\ *corresponding author
}

\section{INFORMASI ARTIKEL \\ Dikirim : 21 Oktober 2020 \\ Diulas :02 Desember 2020 \\ Direvisi : 11 Desember 2020 \\ Diterbitkan : 28 Desember 2020}

Kata Kunci: (8 PT)

Tumbuhan berkhasiat obat

AHP

WP

Sistem pendukung keputusan

\section{ABSTRAK}

Kalimantan memiliki hutan dengan keanekaragaman hayatinya dan menjadi salah satu paru-paru dunia serta ditunjang juga dengan potensi pengetahuan pengobatan tradisional yang dimiliki berbagai etnis asli di Kalimantan. Umumnya pengetahuan pengobatan tradisional menggunakan tumbuhan berkhasiat obat dikuasai generasi tua. Generasi muda mulai kurang tertarik menggali pengetahuan ini sehingga akan membuat pengetahuan ini terkikis dan mulai ditinggalkan. Salah satu faktor penyebabnya karena kurangnya sebaran pengetahuan akibat dari pendokumentasian yang masih terpisah-pisah sehingga dibutuhkan sarana pendokumentasian. Sistem pendukung keputusan yang dibangun bertujuan untuk memberikan rekomendasi tumbuhan yang berkhasiat untuk mengobati atau menangani suatu penyakit serta dapat menjadi salah satu sarana pendokumentasian dengan memberikan informasi seputar tumbuhan berkhasiat obat. Sistem ini mengimplementasikan dua metode yaitu Analytical Hierarchy Process (AHP) digunakan pada tahap penentuan bobot kriteria dan Weighted Product (WP) yang digunakan untuk mengevaluasi alternatif tumbuhan berkhasiat obat. Sistem melibatkan 4 kriteria dalam pengambilan keputusan yaitu bagian yang berkhasiat, carapengolahan, cara penggunaan dan jenis tumbuhan serta terdapat 29 jenis tumbuhan berkhasiat obat untuk 33 jenis penyakit. Output dari sistem ini berupa urutan prioritas tumbuhan berkhasiat obat yang direkomendasikan pada suatu penyakit. Dengan dibuatnya Sistem Pendukung Keputusan penentuan tumbuhan berkhasiat obat etnis Kalimantan diharapkan mampu mempermudah dalam penentuan penggunaan tumbuhan berkhasiat obat.
Keywords:

Medicinal plants

AHP

WP

Decision support system

\section{ABSTRACT}

Kalimantan has rich biodiversity is also supported by the potential of traditional knowledge of various indigenous ethnicities Kalimantan. In general, knowledge of traditional medicine using medicinal plants is only controlled by the elderly. Today, the younger generation is less motivated to gather knowledge from the elders and is slowly starting to be forgotten because documentation is still fragmented so that documentation is needed. The decision support system that was built aims to provide recommendations for medicinal plants to treat disease and can be a means of documenting by providing information about medicinal plants. This system implements two methods, namely the Analytical Hierarchy Process (AHP) which is used to determine the weight of the criteria, and the Weighted Product (WP) which is used to evaluate alternatives to medicinal plants. he system involves 4 criteria in decision making, namely the plants part, the method of processing, the method of use, and the types of plants. There are 29 types of medicinal plants for 33 types of diseases. The output of this system is in the form of a priority order of recommended medicinal plants for the disease. The building of a decision support system for the determination of medicinal plants for the Kalimantan ethnic, it is hoped that it will be able to facilitate the determination of the use of medicinal plants.

This is an open access article under the CC-BY-SA license. 


\section{Pendahuluan}

Indonesia memiliki kekayaan keanekaragaman hayati yang sangat besar dan menjadi salah satu aset bangsa yang wajib dijaga kelestariannya dan dimanfaatkan dengan bijaksana. Kalimantan merupakan pulau di Indonesia yang memiliki hutan dengan keanekaragaman hayatinya dan menjadi salah satu paru-paru dunia. Selain memiliki kekayaan keanekaragaman hayati tetapi ditunjang juga dengan potensi pengetahuan tradisional yang dimiliki berbagai etnis asli di Kalimantan dan adanya keterkaitan terhadap budaya masyarakat setempat. Pemanfaatan kekayaan hayati oleh masyarakat di Kalimantan yaitu pada pengobatan tradisional etnis lokal menggunakan beragam jenis tumbuhan yang memiliki khasiat obat. Sebagian ilmu pengobatan tradisional ini telah teruji secara empiris turun temurun dari leluhur nenek moyang [1]-[7].

Pengetahuan pengobatan tradisional ini diturunkan dari generasi ke generasi, namun saat ini kebanyakan dipahami hanya oleh kaum tua. Generasi muda mulai kurang tertarik menggali pengetahuan ini dari kaum tua sehingga akan membuat pengetahuan ini terkikis dan mulai ditinggalkan. Salah satu faktor penyebab hal ini terjadi karena kurangnya sebaran pengetahuan akibat dari pendokumentasian yang masih terpisah-pisah [6]. Untuk mengatasi hal tersebut maka perlu dilakukan kegiatan mendokumentasikan pengetahuan pengobatan tradisional yang memanfaatkan tumbuhan berkhasiat obat. Salah satu cara pendokumentasian tersebut adalah melalui media Sistem Informasi yang didalamnya didukung sistem untuk membantu memilih tumbuhan obat yang sesuai dengan kebutuhan pengguna, untuk membangun sistem tersebut dapat menggunakan sistem pendukung keputusan. Dalam sistem pendukung keputusan untuk membuat urutan prioritas alternatif pilihan yang melibatkan beberapa kriteria dibutuhkan sebuah model pengambilan keputusan yaitu Multi-Attribute Decision Making (MADM). Metode-metode MADM dalam membentuk urutan prioritas alternatif harus mendefensikan bobot kriteria yang akan digunakan. Bobot kriteria tersebut bisa berasal dari pengambil keputusan berupa bobot subjektif atau berupa bobot objektif, bobot objektif adalah dengan menggali informasi bobot dari data set yang ada. Salah satu cara pembobotan objektif yaitu melalui metode Analitycal Hierarchy Process (AHP).

Sebelumnya telah dilakukan penelitian yang menghasil sistem informasi dan database tumbuhan berkhasiat obat di hutan tropis Kalimantan, dimana tumbuhan yang berhasil dikumpulkan dan diidentifikasi khasiatnya sebanyak 233 spesies [4]. Selain itu, pada penelitian sebelumnya diterapkan metode Simple Additive Weighting dalam pemilihan tanaman obat [8]. Penelitian yang lain menggunakan metode TOPSIS dalam menentukan tanaman obat untuk suatu penyakit [9] serta terdapat penelitian yang menghasilkan aplikasi penentuan tanaman obat herbal berbagai penyakit menggunakan metode rank order centroid dan ORESTE [10].

Sistem pendukung keputusan pemilihan tumbuhan berkhasiat obat dibangun menggunakan metode AHP untuk menentukan bobot dari setiap kriteria dengan membandingkan tingkat kepentingan setiap krtieria yang ada dan metode Weigted Product (WP) untuk penentuan urutan prioritas alternatif. WP adalah salah satu metode dalam MADM yang dapat diimplementasikan pada sistem pengambilan keputusan sehingga pengambilan keputusan dapat dilakukan secara cepat dan tepat serta sesuai kriteria yang diinginkan atau mendekati kriteria yang diinginkan. Alternatif keputusan yang diharapkan dapat memberikan daftar reference kepada pengambil keputusan sebelum membuat keputusan akhir.

\section{Metode}

\section{A. Tumbuhan Berkhasiat Obat}

Data tumbuhan berkhasiat obat diperoleh dari Balai Penelitian Teknologi Koservasi Sumbedaya Alam (Balitek KSDA) Samboja sebanyak 29 tumbuhan dengan jenis pohon, paku-pakuan dan epifit. Tumbuhan berkhasiat obat ini dapat dimanfaatkan untuk menngobati atau menangani 33 jenis penyakit yang disajikan pada Tabel 1.

\begin{tabular}{|c|c|c|c|c|c|}
\hline No & Penyakit & No & Penyakit & No & Penyakit \\
\hline 1 & Diabetes & 12 & Anti Kanker & 23 & Flu dan pilek \\
\hline 2 & Ginjal & 13 & Leukimia & 24 & Ambeyen \\
\hline 3 & Kurap & 14 & Peluru Keringat & 25 & Asma \\
\hline 4 & Gatal-gatal & 15 & Peluruh air seni & 26 & Sesak nafas \\
\hline 5 & Sakit Pinggang & 16 & Sakit kepala & 27 & Bisul \\
\hline 6 & Malaria & 17 & Luka & 28 & Rematik \\
\hline 7 & Cacingan & 18 & Kudis & 29 & Usus buntu \\
\hline 8 & Diare & 19 & Disentri & 30 & Keputihan \\
\hline 9 & Hipertensi & 20 & Tumor & 31 & Impotensi \\
\hline 10 & Peluru kentut & 21 & Batuk & 32 & Anemia \\
\hline 11 & Antirematik & 22 & Demam & 33 & Kencing batu \\
\hline
\end{tabular}


Dalam pemilihan tumbuhan berkhasiat obat untuk suatu jenis penyakit melibatkan 4 kriteria yang dijadikan bahan pertimbangan yaitu bagian tumbuhan yang berkhasiat, cara pengolahan, cara penggunaan dan jenis tumbuhan yang disajikan pada Tabel 2.

Tabel 2. Kriteria dan subkriteria

\begin{tabular}{|c|c|c|c|}
\hline Kriteria & Bobot kriteria & Subkriteria & Bobot subkriteria \\
\hline \multirow{5}{*}{ Bagian yang Berkhasiat (K1) } & \multirow{5}{*}{0,44} & Daun & 0,2540 \\
\hline & & Akar & 0,4286 \\
\hline & & Kulit Batang & 0,2063 \\
\hline & & Buah & 0,0794 \\
\hline & & Biji & 0,0317 \\
\hline \multirow{6}{*}{ Cara pengolahan (K2) } & \multirow{6}{*}{0,32} & Dihaluskan & 0,1905 \\
\hline & & Ddikupas & 0,0159 \\
\hline & & Diperas & 0,0159 \\
\hline & & Direbus & 0,7302 \\
\hline & & Direndam & 0,0159 \\
\hline & & Ditumbuk & 0,0317 \\
\hline \multirow{4}{*}{ Carapenggunaan (K3) } & \multirow{4}{*}{0,17} & Dimakan & 0,0159 \\
\hline & & Digunakan mandi & 0,0159 \\
\hline & & Diminum & 0,8254 \\
\hline & & Dioleskan & 0,1429 \\
\hline \multirow{3}{*}{ Jenis Tumbuhan (K4) } & \multirow{3}{*}{0,07} & Pohon & 0,8889 \\
\hline & & Paku-pakuan & 0,0794 \\
\hline & & Epifit & 0,0317 \\
\hline
\end{tabular}

\section{B. Sistem Pendukung Keputusan}

Sistem pendukung keputusan merupakan sistem terkomputerisasi untuk membantu para pembuat keputusan manajerial dalam persoalan keputusan semi-terstruktur. Sistem pendukung keputusan diperuntukkan sebagai tools bantu bagi para pembuat keputusan untuk memperluas kapabilitas mereka dalam mengevaluasi dan membuat keputusan sesuai dengan pola penilaian mereka sehingga tools ini tidak untuk menggantikan penilaian para pengambil keputusan [11], [12].

\section{Metode Analittycal Hierarchy Process (AHP)}

Pada penelitian ini, metode AHP digunakan dalam menentukan bobot kriteria dikarenakan data awal dari kriteria yang digunakan tidak dalam bentuk data kuantitatif. AHP membuat persoalan yang kompleks dan luas dimana data dan informasi statistik dari masalah yang dihadapi sangat sedikit dan tidak terstruktur menjadi model yang sederhana dan fleksibel [12]. Penentuan bobot kirteria berdasarkan langkah-langkah metode AHP [13]-[17].

\section{Metode Wighted Product (WP)}

Weighted Product (WP) merupakan salah satu metode dalam MADM yang menggunakan operator total perkalian dalam menghubungkan rating atribut, dimana rating setiap atribut dipangkatkan dengan bobot yang dimiliki masing-masing kriteria. Pada peneltian ini, metode WP digunakan untuk mengurutkan prioritas alternatif keputusan karena metode WP lebih simpel dibandingkan metode Multi-Criteria Decision Making (MCDM) lainnya, perhitungannya tidak begitu kompleks dan mudah dipahami [18], [19]. Penentuan prioritas alternatif dalam memberikan rekomendasi keputusan mengikuti langkah-langkah metode WP [20]-[22].

\section{Hasil dan Pembahasan}

Berdasarkan 29 jenis tumbuhan berkhasiat obat yang dapat dimanfaatkan untuk mengobati atau menangani 33 jenis penyakit maka terbentuk dataset yang digunakan sebagai rating kecocokan setiap alternatif pada setiap kriteria dan selanjutnya digunakan dalam mengevaluasi alternatif yaitu pemilihan tumbuhan berkhasiat obat sesuai dengan jenis penyakit yang dipilih. Adapun dataset tumbuhan berkhasiat obat disajikan pada Tabel 3.

Tabel 3. Dataset Tumbuhan Berkhasiat Obat

\begin{tabular}{clccccc}
\hline No & Nama Tumbuhan & $\begin{array}{c}\text { Bagian } \\
\text { Berkhasiat }\end{array}$ & $\begin{array}{c}\text { Cara } \\
\text { Pengolohan }\end{array}$ & $\begin{array}{c}\text { Cara } \\
\text { Penggunaan }\end{array}$ & Jenis & Penyakit \\
\hline 1 & Limpasu & Daun & direbus & Diminum & Pohon & Diabetes \\
2 & Ulin & Daun & ditumbuk & Dioleskan & Pohon & Ginjal \\
3 & Sahang Burung & Buah & dikupas & Dimakan & Pohon & Diabetes \\
\hline
\end{tabular}




\begin{tabular}{clcccccc}
\hline No & Nama Tumbuhan & $\begin{array}{c}\text { Bagian } \\
\text { Berkhasiat }\end{array}$ & $\begin{array}{c}\text { Cara } \\
\text { Pengolohan }\end{array}$ & $\begin{array}{c}\text { Cara } \\
\text { Penggunaan }\end{array}$ & Jenis & Penyakit \\
\hline 4 & Sahang Burung & Daun & dihaluskan & Dioleskan & Pohon & Gatal-gatal \\
5 & Sahang Burung & Daun & dihaluskan & Dioleskan & Pohon & Sakit Pinggang \\
6 & Sahang Burung & Daun & dihaluskan & Dioleskan & Pohon & Kurap \\
7 & Sahang Burung & Akar & direbus & Diminum & Pohon & Cacingan \\
8 & Sahang Burung & Akar & direbus & Diminum & Pohon & Diare \\
9 & Sahang Burung & Akar & direbus & Diminum & Pohon & Malaria \\
10 & Jengkol & Akar & direbus & Diminum & Pohon & Diabetes \\
$\vdots$ & $\vdots$ & $\vdots$ & $\vdots$ & direbus & Diminum & epifit & Tumor \\
63 & Benalu/ Kayu Singgah & Daun & & & & $\vdots$ \\
\hline
\end{tabular}

A. Metode Analittycal Hierarchy Process (AHP)

Dalam penentuan alternatif tumbuhan berkhasiat obat dibutuhkan bobot dari setiap kriteria yang digunakan. Metode AHP diterapkan dalam penentuan bobot setiap kriteria yaitu bobot kriteria Bagian Tumbuhan (K1), Cara Pengolahan (K2) Cara Penggunaan (K3) dan Jenis Tumbuhan (K4). Langkah-langkah menentukan bobot setiap kriteria menggunakan metode AHP sebagai berikut:

1. Membentuk Hirarki proses.

Langkah awal dari metode ini yaitu menefinisikan tingkat kepentingan antar kriteria dalam mengevaluasi alternatif yang diperoleh dari Balitek SDA sebagai berikut:

a. K1 mendekati sedikit lebih penting dari K2 dengan bobot 2

b. K1 sedikit lebih penting dari K3 dengan bobot 3

c. K1 mendekati lebih penting dari K4 dengan bobot 4

d. K2 sedikit lebih penting dari K3 dengan bobot 3

e. K2 lebih penting dari K4 dengan bobot 5

f. K3 mendekati lebih penting dari K4 dengan bobot 4

2. Membuat matriks perbandingan berpasangan kriteria

Berdasarkan tingkat kepentingan antar kriteria yang telah ditentukan maka terbentuk matriks berpasangan kriteria yang disajika pada Tabel 4 .

Tabel 4. Matriks Berpasangan Kriteria

\begin{tabular}{|c|c|c|c|c|}
\hline Kriteria & K1 & K2 & K3 & K4 \\
\hline K1 & 1 & 2 & 3 & 4 \\
\hline K2 & 0,5 & 1 & 3 & 5 \\
\hline K3 & 0,33 & 0,333333 & 1 & 4 \\
\hline K4 & 0,25 & 0,2 & 0,25 & 1 \\
\hline Jumlah & $\mathbf{2 , 0 8}$ & $\mathbf{3 , 5 3}$ & $\mathbf{7 , 2 5}$ & $\mathbf{1 4}$ \\
\hline
\end{tabular}

3. Menentukan nilai priority vector

Langkah selanjutnya adalah menentukan nilai priority vector untuk setiap kriteria menggunakan persamaan (1) berikut ini:

$$
A_{x y}=\frac{K_{x y}}{\text { Jumlah kolom elemen ke-y }}
$$

sehingga diperoleh hasil sebagai berikut:

$$
\begin{aligned}
& A_{(k 1, k 1)}=\frac{1}{2,08333}=0,48 \\
& A_{(k 1, k 2)}=\frac{2}{3,5333}=0,56 \\
& \vdots \\
& A_{(k 4, k 4)}=\frac{1}{14}=0,071
\end{aligned}
$$

Berdasarkan hasil yang diperoleh pada persamaan (1), perhitungan dilanjutkan dengan menggunakan persamaan (2) sehingga diperoleh hasil berikut:

$$
\text { Priority Vector }\left(P V_{x}\right)=\frac{\text { Jumlah Baris }}{\text { Jumlah Kriteria }}=\frac{\sum_{y=1}^{n} A_{x y}}{n}
$$

Untuk kriteria K1:

$$
P V_{K 1}=\frac{(0,48+0,56+0,41+0,29)}{4}=0,44
$$


Untuk kriteria K2:

$$
\begin{aligned}
& P V_{K 2}=\frac{(0,24+0,28+0,41+0,36)}{4}=0,32 \\
& P V_{K 3}=\frac{(0,16+0,09+0,14+0,28)}{4}=0,17 \\
& P V_{K 4}=\frac{(0,12+0,06+0,03+0,07)}{4}=0,07
\end{aligned}
$$

Berdasarkan hasil yang diperoleh maka matriks priority vector kriteria yang disajikan pada Tabel 5 berikut.

Tabel 5. Priority Vector Kriteria

\begin{tabular}{|c|c|c|c|c|c|}
\hline & K1 & K2 & K3 & K4 & Priority Vector \\
\hline K1 & 0,48 & 0,56 & 0,41 & 0,29 & 0,44 \\
\hline K2 & 0,24 & 0,28 & 0,41 & 0,36 & 0,32 \\
\hline K3 & 0,16 & 0,09 & 0,14 & 0,29 & 0,17 \\
\hline K4 & 0,12 & 0,06 & 0,03 & 0,07 & 0,07 \\
\hline
\end{tabular}

4. Menentukan Eigen Value Maksimum $\left(\lambda_{\max }\right)$

Dalam menentukan nilai Eigen maksimum dari matriks perbandingan berpasangan kriteria digunakan persamaan (3) sehingga diperoleh hasil sebagai berikut:

$$
\begin{aligned}
& \lambda_{\max }=\sum K_{x y} * P V_{x} \\
& \lambda_{\max }=1,8744+1,4033+0,7053+0,2867=4,2697
\end{aligned}
$$

Penentuan nilai Eigen maksimum merupakan langkah awal dalam menguji tingkat konsistesi dari matriks perbandingan berpasangan kriteria.

5. Menentukan Consistency Index (CI)

Berdasarkan Eigen Value Maksimum yang telah diperoleh maka selanjutnya menentukan Consistency Index menggunakan persamaan (4) sehingga diperoleh hasil berikut:

$$
\begin{aligned}
& C I=\frac{\left(\lambda_{\max }-n\right)}{(n-1)}, \text { dimana } n \text { banyaknya kriteria yang dilibatkan } \\
& C I=\frac{(4,2697-4)}{(4-1)}=0,0899
\end{aligned}
$$

6. Mencari nilai Consistency Ratio (CR)

Penentuan Consistency Ratio (CR) matriks perbandingan berpasangan kriteria menggunakan persamaan (5) sehingga diperoleh hasil berikut:

$$
\begin{aligned}
& C R=\frac{C I}{R I}, \text { dimana nilai RI berdasarkan tabel Random Index AHP } \\
& C R=\frac{0,089992}{0,9}=0,09
\end{aligned}
$$

Nilai Consistency Ratio (CR) menunjukkan CR < 0,1 yaitu sebesar 0,09. Hal ini menggambarkan maka matriks perbandingan berpasangan kriteria yang terbentuk dinyatakan konsisten sehingga nilai Priority vector kriteria dapat digunakan sebagai bobot kriteria dalam mengevaluasi alternatif tumbuhan berkhasiat obat yang disajikan pada Tabel 6 .

Tabel 6. Bobot Kriteria Pemilihan Pemilihan Tumbuhan Berkhasiat Obat

\begin{tabular}{lc}
\hline \multicolumn{1}{c}{ Kriteria } & Bobot Kriteria \\
Bagian yang berkhasiat (K1) & 0,44 \\
Cara Pengolahan (K2) & 0,32 \\
Cara Penggunaan (K3) & 0,17 \\
Jenis Tanaman (K4) & 0,07 \\
\hline
\end{tabular}

\section{B. Metode Weighted Product (WP)}

WP diterapkan untuk mengevaluasi alternatif dalam pemilihan tumbuhan berkhasiat obat untuk suatu penyakit berdasarkan kriteria yang dilibatkan, dimana bobot kriteria didefinisikan berdasarkan bobot yang 
dihasilkan oleh metode AHP. Langkah-langkah metode WP dalam merekomendasikan tumbuhan berkhasiat obat pada suatu penyakit sebagai berikut:

1. Membentuk matriks keputusan alternatif

Pada langkah ini dibentuk matriks keputusan alternatif yaitu rating kecocokan setiap alternatif untuk setiap kriteria pada suatu penyakit. Pada penyakit kanker, akan dievaluasi alternatif tumbuhan berkhasiat obat yang paling direkomendasikan sebagai anti kanker berdasarkan dataset pada Tabel 3 sehingga terbentuk matriks keputusan alternatif tumbuhan berkhasiat obat pada penyakit kanker yang disajikan pada Tabel 7.

Tabel 7. Matriks Keputusan Alternatif Tumbuhan Berkhasiat Obat pada Penyakit Kanker

\begin{tabular}{lcccc}
\hline Tumbuhan Berkhasiat Obat & K1 & K2 & K3 & K4 \\
\hline Pasak Bumi & 0,889 & 0,429 & 0,825 & 0,730 \\
Paku Atei & 0,079 & 0,254 & 0,825 & 0,730 \\
Benalu/ Kayu Singgah & 0,032 & 0,254 & 0,825 & 0,730 \\
\hline
\end{tabular}

2. Menentukan nilai $S_{i}$ setiap alternatif

Langkah selanjutnya, setiap alternatif dicari nilai $S_{i}$ nya berdasarkan Tabel 7 menggunakan persamaan (6) dimana semua kriteri bertipe benefit sehingga diperoleh hasil berikut:

$$
\begin{aligned}
& S_{i}=\prod_{j}^{n} x_{i j}^{w j} \\
& S_{\text {Pasak Bumi }}=\left(0,889^{0,44}\right) *\left(0,426^{0,32}\right) *\left(0,825^{0,17}\right) *\left(0,73^{0,07}\right)=0,6855 \\
& S_{\text {Paku Atei }}=\left(0,0793^{0,44}\right) *\left(0,253^{0,32}\right) *\left(0,825^{0,17}\right) *\left(0,73^{0,07}\right)=0,20028 \\
& S_{\text {Benalu }}=\left(0,0317^{0,44}\right) *\left(0,253^{0,32}\right) *\left(0,825^{0,17}\right) *\left(0,73^{0,07}\right)=0,1338
\end{aligned}
$$

3. Menghitung nilai preferensi setiap alternatif $\left(V_{i}\right)$

Setelah nilai $S_{i}$ pada setiap alternatif diperoleh maka selanjutnya menentukan nilai preferensi untuk setiap alternatif menggunakan persamaan (7).

$$
\begin{aligned}
& V_{i}=\frac{s_{i}}{\sum_{i=1}^{m} s_{i}} \\
& V_{\text {Pasak Bumi }}=\frac{0,6855}{0,6855+0,20028+0,1338}=0,67 \\
& V_{\text {Paku Atei }}=\frac{0,20028}{0,6855+0,20028+0,1338}=0,196 \\
& V_{\text {Benalu }}=\frac{0,1338}{0,6855+0,20028+0,1338}=0,13
\end{aligned}
$$

4. Menentukan prioritas alternatif keputusan

Langkah terakhir dari metode WP dalam mengevaluasi alternatif tumbuhan berkhasiat obat yaitu dengan mengurutkan setiap alternatif berdasarkan nilai $V_{i}$, dimana alternatif dengan nilai $V_{i}$ terbesar merupakan alternatif terbaik untuk dijadikan sebagai rekomendasi keputusan. Urutan prioritas alternative keputusan ditampilkan pada Tabel 8.

Tabel 8. Urutan Rekomendasi Alternatif Keputusan

\begin{tabular}{lcc}
\hline \multicolumn{1}{c}{ Tumbuhan Berkhasiat Obat } & $\boldsymbol{V}_{\boldsymbol{i}}$ & Prioritas \\
\hline Pasak Bumi & 0,67 & 1 \\
Paku Atei & 0,196 & 2 \\
Benalu/ Kayu Singgah & 0,13 & 3 \\
\hline
\end{tabular}

Berdasarkan Tabel 8, tumbuhan berkhasiat obat yg paling direkomendasikan sebagai anti kanker adalah tumbuhan Pasak Bumi berdasarkan kriteria yang dilibatkan.

\section{Sistem Pendukung Keputusan Pemilihan Tumbuhan Berkhasiat Obat}

Sistem pendukung keputusan pemilihan tumbuhan obat menggunakan metode AHP-WP dibangun menggunakan bahasa pemrogram PHP dan berbasis website. Antarmuka dari sistem pendukung keputusan yang dibangun sebagai berikut. 
1. Tampilan halaman awal pengguna

Halaman awal pengguna menampilakan data tumbuhan pohon, paku-pakuan dan epifit yang berkhasiat obat yang menjadi aternatif keputusan untuk suatu penyakit. Halaman awal pengguna dalam system ini ditampilkan pada Gambar 1.

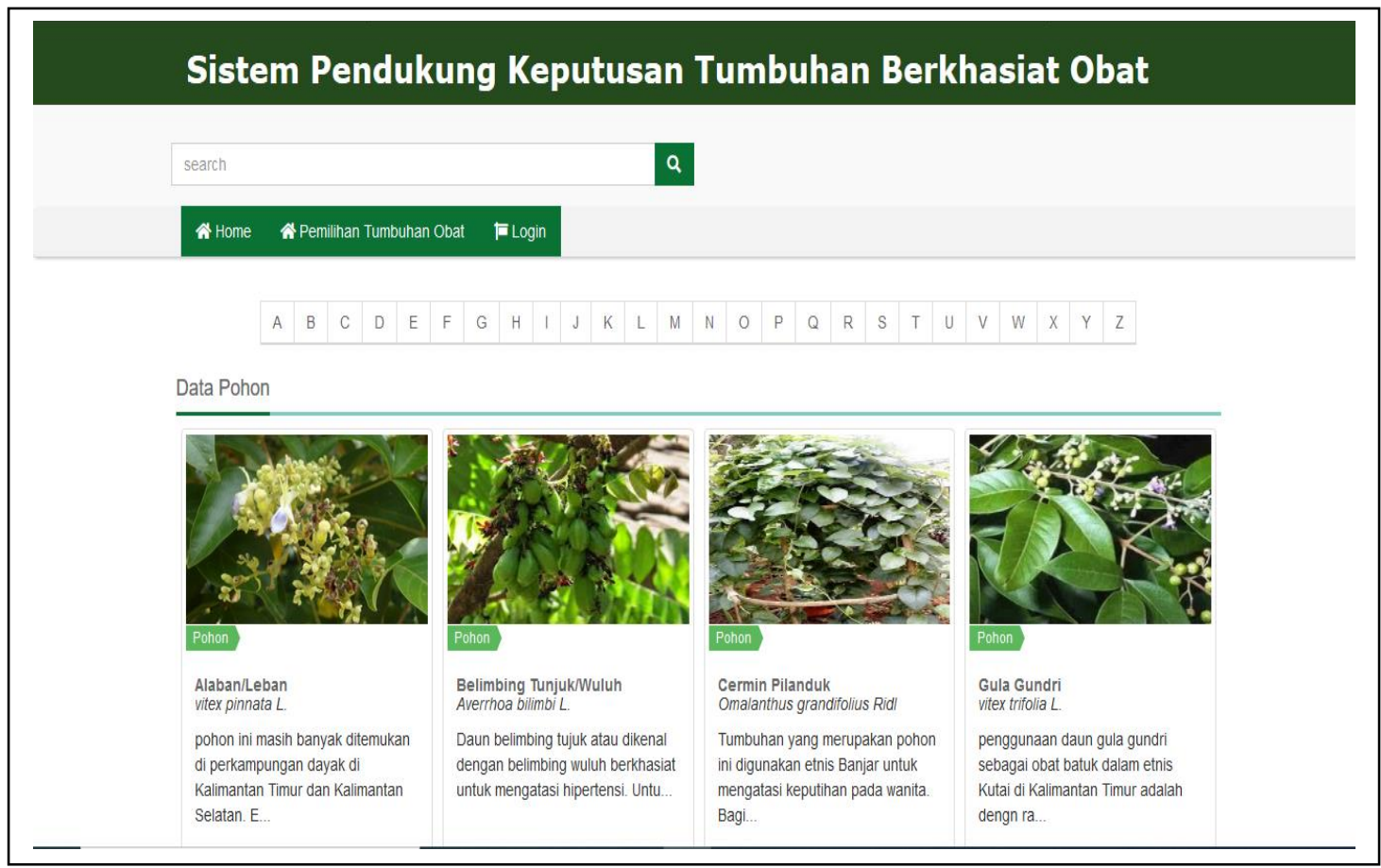

Gambar 1. Antarmuka halaman awal pengguna

2. Tampilan Halaman kriteria pemilihan tumbuhan berkhasiat obat

Pada halaman ini pengguna memilih jenis penyakit yang ingin ditentukan tumbuhan berkhasiat obat yang di rekomendasikan kemudian memilih sub kriteria untuk setiap kriteria yang akan dilibatkan dalam proses evaluasi alternatif. Antaramuka Halaman kriteria pemilihan tumbuhan berkhasiat obat ditampilkan pada Gambar 2.

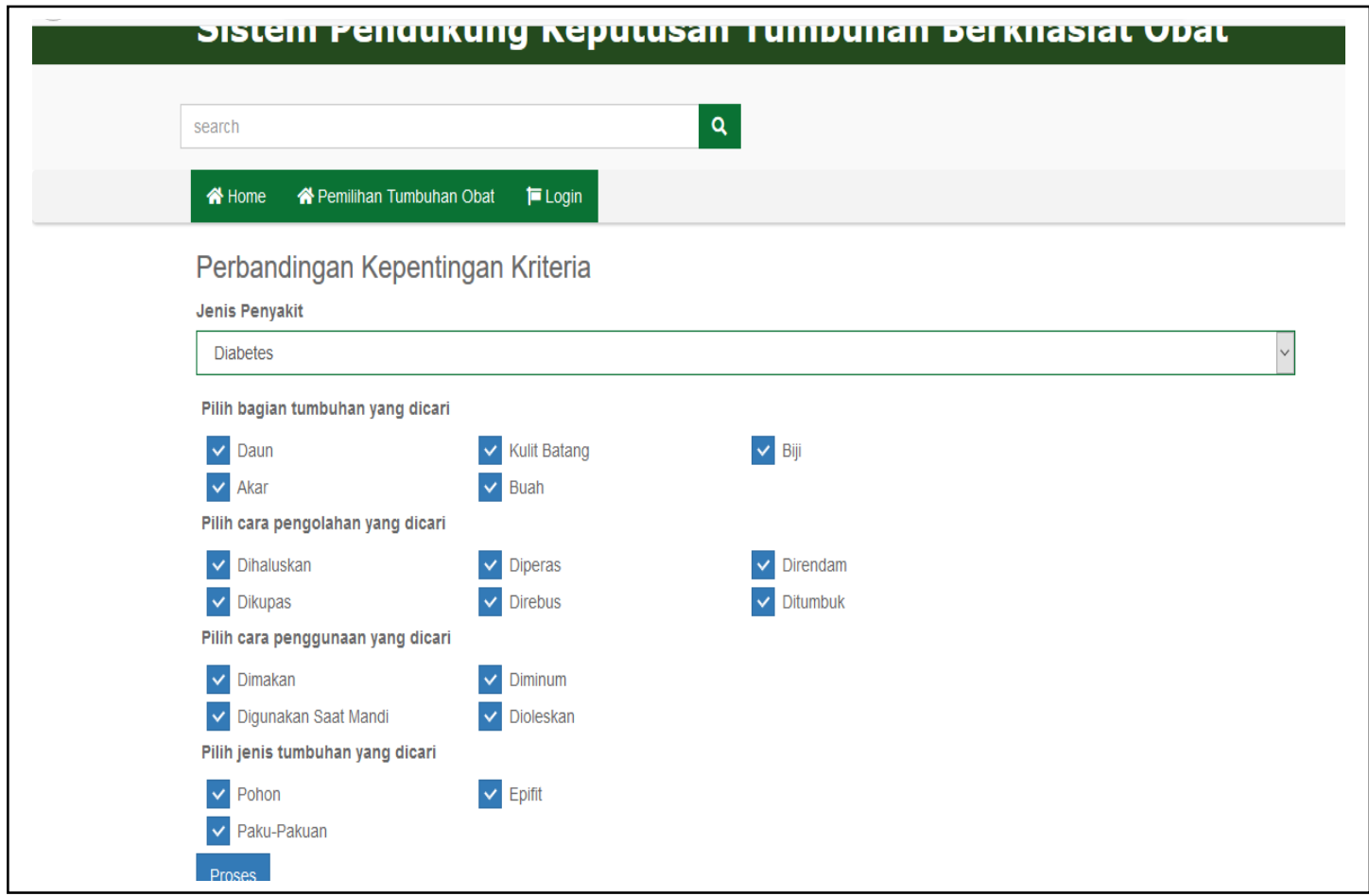

Gambar 2. Antarmuka kriteria pemilihan tumbuhan berkhasiat obat 
3. Tampilan urutan rekomendasi alternatif tumbuhan berkhasiat obat

Pengguna dapat melihat hasil dari pengurutan rekomendasi alternatif tumbuhan berkhasiat obat berdasarkan jenis penyakit dan tingkat kepentingan kriteria yang di inputkan sebelumnya. Antarmuka urutan rekomendasi alternatif tumbuhan berkhasiat obat ditampilkan pada Gambar 3.

\begin{tabular}{|c|c|c|c|c|c|c|}
\hline \multicolumn{3}{|l|}{ search } & \multicolumn{4}{|l|}{$\mathbf{Q}$} \\
\hline 岺 Home & ÂPemilihan Tumbuhan Obat & F Login & & & & \\
\hline \multicolumn{7}{|c|}{ Hasil Perangkingan Alternatif Tumbuhan } \\
\hline No Gambar & Tumbuhan & Jenis Tumbuhan & Bagian Tumbuhan & Cara Penggunaan & Cara Pengolahan & Nila \\
\hline 1 & Jengkol & Pohon & Akar & Diminum & Direbus & 1 \\
\hline 2 & Kayu Manis & Pohon & Akar & Diminum & Direbus & 1 \\
\hline 3 & Pasak Bumi & Pohon & Akar & Diminum & Direbus & 1 \\
\hline $4 R$ & Karatau & Pohon & Akar & Diminum & Direbus & 1 \\
\hline 5 & Limpasu & Pohon & Daun & Diminum & Direbus & 2 \\
\hline
\end{tabular}

\section{Kesimpulan}

Gambar 3. Antarmuka urutan rekomendasi alternatif tumbuhan berkhasiat obat

Berdasarkan hasil penelitian sistem pendukung keputusan pemilihan tumbuhan berkhasiat obat maka diperoleh yaitu sistem yang dibangun berbasis website dengan menerapkan metode AHP dan WP dimana melibatkan 4 kriteria yang digunakan yaitu bagian yang berkhasiat, cara pengolahan, carapenggunaan, jenis tumbuhan dan terdapat 29 jenis tumbuhan untuk 33 jenis penyakit. Proses evaluasi alternatif tumbuhan berkhasiat obat menggunakan metode WP berdasarkan bobot kriteria yang dihasilkan oleh metode AHP. Output yang dihasilkan oleh sistem berupa urutan rekomendasi alternatif tumbuhan berkhasiat obat untuk setiap jenis penyakit.

Pengembangan untuk penelitian selanjutnya perlu yang dilakukan yaitu menganalisis bobot kriteria yang digunakan pada proses evaluasi alternatif serta kriteria-kriteria lain yang perlu dilibatkan dalam memberikan rekomendasi tumbuhan berkhasiat obat untuk suatu penyakit. Penerapan metode MADM lainnya perlu dilakukan untuk membandingkan hasil rekomedasi alternatif yang diberikan sehingga dapat ditentukan metode yang paling relevan untuk diimplementasikan dalam sistem pendukung keputusan pemilihan tumbuhan berkhasiat obat ini.

\section{Ucapan Terima Kasih}

Kami menberikan ucapan terima kasih kepada pihak Balai Penelitian Teknologi Koservasi Sumbedaya Alam (Balitek KSDA) Samboja atas bantuan yang diberikan berupa menyediakan data yang dibutuhkan dalam penyusunan artikel ilmiah ini.

\section{Daftar Pustaka}

[1] E. Budiman, U. Hairah, Haeruddin, A. Tejawati, S. Darmawan, and S. Wahyuni, "Biodiversity Information System of Medicinal Plants from Tropical Rainforest Borneo Based on Traditional Knowledge Ethnic of Dayak," Adv. Sci. Lett., vol. 24, no. 11, pp. 8668-8673, 2018, doi: 10.1166/asl.2018.12321.

[2] E. Budiman and U. Hairah, "Manajemen Database Dan Sistem Informasi Keanekaragaman Hayati 
Tanaman Berkhasiat Obat Etnis Asli Kalimantan,” Jurti, vol. 1. pp. 73-80, 2017.

[3] K. Asa, E. Budiman, and H. S. Pakpahan, "Pengembangan Sistem Informasi Keanekaragaman Hayati Data Pohon Dan Endemik Pada Hutan Hujan Tropis Kalimantan,” Pros. Semin. Nas. Ilmukomputer dan Teknol. Inf., vol. 2, no. 2, 2017, doi: 10.1016/j.biomaterials.2008.08.026.

[4] J. A. Widians, M. Wati, A. Tejawati, and E. Budiman, "Biodiversity Information System for Management of Medicinal Plants Data Tropical Rainforest Borneo," Int. J. Eng. Technol., vol. 7, no. 4.44, p. 31, 2018, doi: 10.14419/ijet.v7i4.44.26858.

[5] N. Dengen, E. Budiman, J. A. Widians, M. Wati, U. Hairah, and M. Ugiarto, "Biodiversity information system: Tropical rainforest borneo and traditional knowledge ethnic of dayak," $J$. Telecommun. Electron. Comput. Eng., vol. 10, no. 1-9, pp. 59-64, 2018.

[6] Noorcahyati, Buku-Tumbuhan-Berkhasiat-Obat-Etnis-Asli-Kalimantan-kcl. 2012.

[7] Noorcahyati and Z. Arifin, "Etnobotani Tumbuhan Berkhasiat Obat Etnis Dayak Meratus Loksado Kalimantan Selatan dan Upaya Konservasi Di KHDTK Samboja," Pros. Semin. BALITEK KSDA, 2014, [Online]. Available: https://www.forda-mof.org//files/Makalah_utama_seminar_obat.pdf.

[8] H. Syafitri, "Sistem Pendukung Keputusan Pemilihan Alternatif Tanaman Obat Menggunakan Metode Simple Additive Weighting," in Prosiding Konferensi Mahasiswa Sistem Informasi (KMSI), 2016, vol. 4, no. 1, doi: http://dx.doi.org/10.21460/inf.2016.122.486.

[9] H. V. Brahmantyo and R. Ariyanto, "Sistem Pendukung Keputusan Penentuan Tanaman Obat Sesuai Jenis Penyakit Menggunakan Metode Topsis," J. Inform. Polinema, vol. 2, no. 2, p. 66, 2016, doi: 10.33795/jip.v2i2.58.

[10] N. Astiani, D. Andreswari, and Y. Setiawan, "Aplikasi Sistem Pendukung Keputusan Tanaman Obat Herbal Untuk Berbagai Penyakit Dengan Metode ROC (Rank Order Centroid) Dan Metode ORESTE Berbasis Mobile Web," J. Teknol. Komput. dan Inform., vol. 12, no. 2, pp. 125-140, 2016, [Online]. Available: https://ti.ukdw.ac.id/ojs/index.php/informatika/article/view/486.

[11] J. A. Widians, Sistem Pendukung Keputusan. Samarinda: FAKULTAS TEKNOLOGI INFORMASI DAN KOMPUTER UNIVERSITAS MULAWARMAN, 2015.

[12] Fazliani, J. A. Widians, and Islamiyah, "Unggul Kelapa Sawit Dengan Metode Analytic Hierarchy Process ( Ahp )," Pros. Semin. Ilmu Komput. dan Teknol. Inf., vol. 2, no. 1, 2017.

[13] E. Marbun and S. Hansun, "Sistem Pendukung Keputusan Pemilihan Program Studi Dengan Metode Saw Dan Ahp,” Ilk. J. Ilm., vol. 11, no. 3, pp. 175-183, 2019, doi: 10.33096/ilkom.v11i3.432.175183.

[14] I. Mahendra and P. K. Putri, "Implementasi Metode Analytical Hierarchy Process (Ahp) Dalam Sistem Pendukung Keputusan Pembelian Rumah Di Kota Tangerang," J. Teknoinfo, vol. 13, no. 1, p. 36, 2019, doi: 10.33365/jti.v13i1.238.

[15] A. A. Tri Susilo and L. Sunardi, "Sistem Pendukung Keputusan Jenis Tanaman Pangan Dengan Metode Analytical Hierarchy Process (Ahp)," JUTIM (Jurnal Tek. Inform. Musirawas), vol. 5, no. 1, pp. 1-10, 2020, doi: 10.32767/jutim.v5i1.838.

[16] M. Rifqi and Dona, "Pemilihan Tanaman Berdasarkan Kondisi Lahan dan Persyaratan Tumbuh Tanaman Menggunakan Gabungan Metode AHP dan TOPSIS," JURTEKSI (Jurnal Teknol. dan Sist. Informasi), vol. VI, no. 3, pp. 201-208, 2020.

[17] C. H. I. Jaya, N. Hidayat, and D. Sihombing, "Sistem Pakar Identifikasi Hama Penyakit Tanaman Sedap Malam Menggunakan Fuzzy Analytical Hierarchy Process ( F-AHP )," J. Pengemb. Teknol. Inf. dan Ilmu Komput. Univ. Brawijaya, vol. 2, no. 1, pp. 313-322, 2018.

[18] M. A. Saputera, A. Tejawati, and M. Wati, "Sistem Pendukung Keputusan Penentuan Penerima Bantuan Daerah Menggunakan Weighted Product," Pros. Semin. Ilmu Komput. dan Teknol. Inf., vol. 2, no. 1, pp. 76-80, 2017.

[19] D. Aldo, "Pemilihan Bibit Lele Unggul Dengan Menggunakan Metode Weighted Product," $J$. Teknol. Dan Open Source, vol. 2, no. 1, pp. 15-23, 2019, doi: 10.36378/jtos.v2i1.138.

[20] M. Wati, "Analisis Metode Weighted Product dan Promethee Dalam Pemilihan Penerima Santunan Warga Tidak Mampu," J. Rekayasa Teknol. Inf., vol. 3, no. 1, pp. 96-105, 2019.

[21] S. Maharani, S. Hermawati, I. F. Astuti, and M. Khairina, "Pemilihan Taman Kanak-kanak Menggunakan Metode Weighted Product di Kecamatan Sungai Kunjang Samarinda," J. Teknol. Inf. dan Ilmu Komput., vol. 5, no. 4, p. 465, 2018, doi: 10.25126/jtiik.201854814.

[22] R. Roni, S. Sumijan, and J. Santony, "Metode Weighted Product dalam Pemilihan Penerima Beasiswa Bagi Peserta Didik," J. RESTI (Rekayasa Sist. dan Teknol. Informasi), vol. 3, no. 1, pp. 8793, 2019, doi: 10.29207/resti.v3i1.834. 